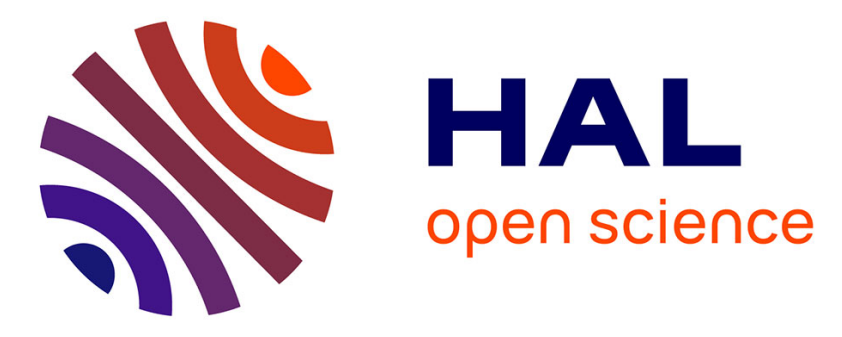

\title{
Enhanced culture recovery of Campylobacter with modified Cary-Blair medium: A practical field experience
}

Clémence Massip, Hélène Guet-Revillet, Marion Grare, Agnés Sommet, Damien Dubois

\section{To cite this version:}

Clémence Massip, Hélène Guet-Revillet, Marion Grare, Agnés Sommet, Damien Dubois. Enhanced culture recovery of Campylobacter with modified Cary-Blair medium: A practical field experience. Journal of Microbiological Methods, 2018, 149, pp.53-54. 10.1016/j.mimet.2018.05.001 . hal02623218

\section{HAL Id: hal-02623218 \\ https://hal.inrae.fr/hal-02623218}

Submitted on 26 May 2020

HAL is a multi-disciplinary open access archive for the deposit and dissemination of scientific research documents, whether they are published or not. The documents may come from teaching and research institutions in France or abroad, or from public or private research centers.
L'archive ouverte pluridisciplinaire HAL, est destinée au dépôt et à la diffusion de documents scientifiques de niveau recherche, publiés ou non, émanant des établissements d'enseignement et de recherche français ou étrangers, des laboratoires publics ou privés.

$$
\text { Copyright }
$$




\section{Accepted Manuscript}

Enhanced culture recovery of Campylobacter with modified CaryBlair medium: A practical field experience

Clémence Massip, Hélène Guet-Revillet, Marion Grare, Agnès Sommet, Damien Dubois

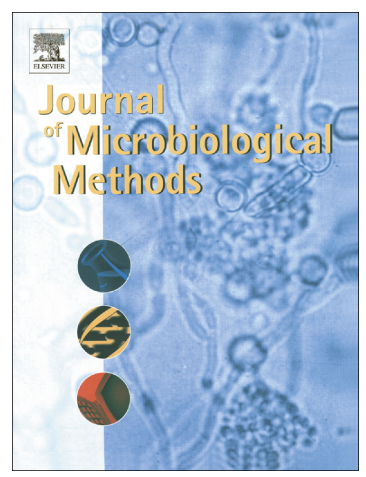

PII:

S0167-7012(18)30035-6

DOI: doi:10.1016/j.mimet.2018.05.001

Reference: MIMET 5384

To appear in: Journal of Microbiological Methods

Received date: 22 January 2018

Revised date: 1 May 2018

Accepted date: 1 May 2018

Please cite this article as: Clémence Massip, Hélène Guet-Revillet, Marion Grare, Agnès Sommet, Damien Dubois, Enhanced culture recovery of Campylobacter with modified Cary-Blair medium: A practical field experience. The address for the corresponding author was captured as affiliation for all authors. Please check if appropriate. Mimet(2018), doi:10.1016/j.mimet.2018.05.001

This is a PDF file of an unedited manuscript that has been accepted for publication. As a service to our customers we are providing this early version of the manuscript. The manuscript will undergo copyediting, typesetting, and review of the resulting proof before it is published in its final form. Please note that during the production process errors may be discovered which could affect the content, and all legal disclaimers that apply to the journal pertain. 
Enhanced culture recovery of Campylobacter with modified Cary-Blair medium: a practical field experience

Clémence MASSIP ${ }^{1,2}$, Hélène GUET-REVILLET ${ }^{1,2}$, Marion GRARE $^{1,2}$, Agnès SOMMET $^{3,4}$,

Damien DUBOIS ${ }^{1,2,{ }^{*}}$ dubois.d@ @hu-toulouse.fr

${ }^{1}$ CHU Toulouse, Service de Bactériologie-Hygiène, Toulouse, France

${ }^{2}$ IRSD, Université de Toulouse, INSERM, INRA, ENVT, UPS, Toulouse, France.

${ }^{3} \mathrm{CHU}$ Toulouse, Service de Pharmacologie Médicale, Unité de Soutien Méthodologique à la Recherche Clinique, Toulouse, France

${ }^{4}$ UMR1027 Inserm / Université Paul Sabatier, Toulouse, France

*Corresponding author.

\section{Abstract:}

Modified Cary-Blair medium derived devices have been implemented in many laboratories to optimize culture recovery of common bacterial enteric pathogens. Our analysis constitutes the first report of routine laboratory experience supporting the idea that the use of such devices enhances Campylobacter recovery from stools.

Keywords: Campylobacter, stool culture, modified Cary-Blair medium

\section{Highlights:}

Culture recovery of common enteric bacterial pathogens in stools remains essential.

Modified Cary-Blair medium performance is studied in clinical laboratory conditions.

Collection in modified Cary-Blair medium improves Campylobacter detection in stools.

Campylobacter commonly causes gastroenteritis worldwide. As Campylobacter are fastidious bacteria, more and more laboratories are adopting specific antigen tests (Fitzgerald et al., 2016) or molecular tests (Zhang et al., 2015) for their detection in stools. 
Since increasing antimicrobial resistances are reported in Campylobacter (Ge et al., 2013), strain isolation remains essential for antimicrobial susceptibility testing and epidemiologic purposes (Couturier, 2016). The modified Cary-Blair (MCB) medium for transport and preservation was recommended to optimize culture recovery of common bacterial enteric pathogens (Campylobacter, Salmonella and Shigella) in stools (Wang et al., 1983). However, the performance of $\mathrm{MCB}$ medium has never been reported in routine clinical laboratory conditions.

In the bacteriology laboratory of the Toulouse University Hospital (France), we retrospectively evaluated the impact of implementation of the MCB medium FecalSwab (Copan, Brescia, Italy) on Campylobacter, Salmonella and Shigella isolation rate from clinical stools. Before 2013, all fecal specimens were collected in dry containers. Since 2013, stools from the Children's Hospital have been collected in FecalSwab devices i.e. a tube with $2 \mathrm{~mL}$ of MCB medium and a flocked swab, whereas adult specimens were still transported in dry containers. To assess the impact of these changes, we compared the distributions of positive samples for each common enteric bacterial pathogen (i.e. Salmonella, Shigella, and Campylobacter) in 2012 and 2014 for children (i.e. patients under the age of 15) and adults using the Chi-square test (statistical significance was defined as a $\mathrm{p}$-value $<0.05$ ). Because MCB medium was implemented in mid-2013, we chose to exclude 2013 from our analysis to avoid any bias due to seasonal variation in common enteric bacterial infections.

During the studied periods, fecal samples were inoculated within 24 hours on Campylosel agar plates (bioMérieux, Marcy-l'Etoile, France) incubated in a micro-aerobic atmosphere at $35 \pm 2{ }^{\circ} \mathrm{C}$ for 48 hours, on Rambach agar plates (VWR International, Radnor, Pennsylvania, USA), Bromocresol Purple agar plates (bioMérieux) and in Selenite broth (Copan) incubated in an aerobic atmosphere at $35 \pm 2{ }^{\circ} \mathrm{C}$ for 24 hours. The Selenite broth was then subcultured onto a Rambach agar plate incubated in an aerobic atmosphere at $35 \pm 2{ }^{\circ} \mathrm{C}$ for 24 hours. All 
suspected colonies were identified by biochemical analyses (API Campy, bioMérieux, for Campylobacter isolates or GN cards on Vitek 2 system bioMérieux, for Salmonella and Shigella) during both periods.

The number of specimens and patient characteristics (number, age) were comparable in 2012 and 2014 (Table 1). Distribution of pediatric samples positive for Campylobacter was significantly different between 2012 and $2014(2.76 \%, \mathrm{n}=50$ vs. 4.35\%, $\mathrm{n}=71 ; \mathrm{p}=0.011)$ whereas no statistical difference was observed for adults $(1.33 \%, \mathrm{n}=59$ vs. $1.62 \%, \mathrm{n}=65$; Table 1). In comparison, the distributions of samples positive for Salmonella or Shigella were not statistically different between 2012 and 2014 for both children and adults. The distribution of Campylobacter species was similar between 2012 and 2014 for both pediatric and adult samples, C. jejuni being the most frequently isolated species.

The specific increase in Campylobacter recovery in pediatric stools between 2012 and 2014 suggests that collection in FecalSwab improves Campylobacter preservation and detection. Indeed, no such trend was observed in adult samples for which dry containers were used for both periods. Of note, no specific Campylobacter, Salmonella or Shigella outbreak was reported during the study. No increase in the incidence of Campylobacter infections was reported by the French National Reference Centre for Campylobacter between 2012 and 2014, although the number of reported cases increased because of the notification system improvement (King et al., 2012; Van Cauteren et al., 2014). In our study, MCB medium implementation led to a global increase in Campylobacter recovery, but it did not enhance the recovery of any specific Campylobacter species. This result should be interpreted with caution because of the small numbers of non-jejuni Campylobacter-positive samples.

The implementation of MCB medium for preservation of pediatric stools up to 24 hours did not lead to an increase in Salmonella or Shigella recovery, as expected according to the 
literature (Altieri et al., 2011). The specific impact on Campylobacter detection might be due to its particular fragility compared to other enteric bacterial pathogens.

MCB medium was shown to be suited for Campylobacter preservation in studies using turkey cecal specimens (Luechtefeld et al., 1981) and for collection of human stools kept at $4^{\circ} \mathrm{C}$ prior to evaluation (Wang et al., 1983). Inoculated with ATCC strains, FecalSwab demonstrated better preserving properties than Amies-based medium which is not an MCB derived medium (Hirvonen and Kaukoranta, 2014). In a study including 125 stools analyzed in accordance with current laboratory procedures, FecalSwab was superior to dry container as a transport device, recovering 10 vs. 7 Campylobacter jejuni strains (Altieri et al., 2011). Conversely to these early side-by-side studies performed on small cohorts and artificially inoculated stools, our analysis was conducted on several thousand samples over 2 years processed with routine laboratory procedures. Our work constitutes the first report of routine laboratory experience supporting the idea that the implementation of MCB derived devices enhances Campylobacter recovery from stools after preservation at room temperature for less than 24 hours. 
Table 1: Characteristics of pediatric and adult stool samples collected in 2012 and 2014

Pediatric stool samples

2012

Dry containers MCB medium
Adult stool samples

2012

2014

Patients

Number of patients

1319

1250

2895

2612

Mean Age (years)

1.88

2.08

61.81

60.46

Standard deviation

3.27

3.49

20.20

20.34

for age (years)

Number of samples

1812

1632

4426

4004

Positive samples

Campylobacter

50

71

59

$65^{\mathrm{ns}}$

(2.76\%)

(4.35\%)

(1.33\%)

(1.62\%)

among which

C. jejuni

45

$59^{\mathrm{ns}}$

$10^{\mathrm{ns}}$

43

$51^{\mathrm{ns}}$

C. coli

4

C. fetus

C. hyointestinalis

C. upsaliensis

Campylobacter sp.

Salmonella

57

-

$-$

$-$

2

9

$7^{\mathrm{ns}}$

3

3

1

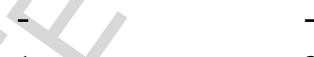

1

$58^{\mathrm{ns}}$

(3.55\%)

24

(3.15\%)

$10^{\mathrm{ns}}$

$(0.54 \%)$

(0.85\%)

Shigella

6

(0.61\%)

7

$9^{\mathrm{ns}}$

$(0.33 \%)$

$(0.16 \%)$

(0.22\%)

\footnotetext{
${ }^{*}$ Statistical difference $(\mathrm{p}<0.05)$ and, ${ }^{\mathrm{ns}}$ No statistical difference between 2012 and 2014 according to Chi-square test.
}

The authors thank the technical staff of the bacteriology laboratory at Toulouse University Hospital for their excellent routine work.

The authors declare no conflict of interest. 


\section{REFERENCES}

Fitzgerald C, Patrick M, Gonzalez A, Akin J, Polage CR, Wymore K, et al. Multicenter evaluation of clinical diagnostic methods for detection and isolation of Campylobacter spp. from stool. J Clin Microbiol 2016;54:1209. doi:10.1128/JCM.01925-15.

Zhang H, Morrison S, Tang Y-W. Multiplex PCR tests for detection of pathogens associated with gastroenteritis. Clin Lab Med 2015;35:461. doi:10.1016/j.cll.2015.02.006.

Ge B, Wang F, Sjölund-Karlsson M, McDermott PF. Antimicrobial resistance in Campylobacter: susceptibility testing methods and resistance trends. J Microbiol Methods 2013;95:57-67. doi:10.1016/j.mimet.2013.06.021.

Couturier MR. Revisiting the roles of culture and culture-independent detection tests for Campylobacter. J Clin Microbiol 2016;54:1186. doi:10.1128/JCM.03221-15.

Wang WL, Reller LB, Smallwood B, Luechtefeld NW, Blaser MJ. Evaluation of transport media for Campylobacter jejuni in human fecal specimens. J Clin Microbiol 1983;18:803-7.

King L, Lehours P, De Valk H, Mégraud F. Bilan de la surveillance des infections à Campylobacter chez l'homme en France en 2012. France: Institut de Veille Sanitaire; 2012. Van Cauteren D, Lehours P, Bessède E, De Valk H, Mégraud F. Bilan de la surveillance des infections à Campylobacter chez l'homme en France en 2014. France: Institut de Veille Sanitaire; 2014.

Altieri A., Bossa M.C., Capalbo F., Di Traglia L., Fontana C. Comparison of the Copan fecal swab to dry containers forcollection and transportation of stool samples for detection of bacteria causing gastrointestinal infection. Clin Microbiol Infect 2011;17:S108-668. doi:10.1111/j.1469-0691.2011.03558.x.

Luechtefeld NW, Wang WL, Blaser MJ, Reller LB. Evaluation of transport and storage techniques for isolation of Campylobacter fetus subsp. jejuni from turkey cecal specimens. J Clin Microbiol 1981;13:438. 
Hirvonen JJ, Kaukoranta S-S. Comparison of FecalSwab and ESwab devices for storage and transportation of diarrheagenic bacteria. $J$ Clin Microbiol 2014;52:2334. doi:10.1128/JCM.00539-14. 